\title{
Feasibility Tests of High Volume Blended Metakaolin-Brick Powder Concrete Incorporating Wastes of Crushed Brick and Plastic as Aggregate
}

\author{
Mahmood Fawzi Ahmed \\ Department Education of Hit - General Directorate of Education in Anbar, Ministry of Education, Iraq
}

Received June 16, 2021; Revised August 17, 2021; Accepted September 8, 2021

\section{Cite This Paper in the following Citation Styles}

(a): [1] Mahmood Fawzi Ahmed, "Feasibility Tests of High Volume Blended Metakaolin-Brick Powder Concrete Incorporating Wastes of Crushed Brick and Plastic as Aggregate, "Civil Engineering and Architecture, Vol. 9, No. 6, pp. 1837-1845, 2020. DOI: 10.13189/cea.2021.090616.

(b): Mahmood Fawzi Ahmed (2021). Feasibility Tests of High Volume Blended Metakaolin-Brick Powder Concrete Incorporating Wastes of Crushed Brick and Plastic as Aggregate. Civil Engineering and Architecture, 9(6), $1837-1845$. DOI: $10.13189 /$ cea.2021.090616.

Copyright $(2021$ by authors, all rights reserved. Authors agree that this article remains permanently open access under the terms of the Creative Commons Attribution License 4.0 International License

\begin{abstract}
Sustainability of the construction industry is taking a priority worldwide. The objective of this work is to evaluate the contribution of double using of waste clay brick and waste plastic for some properties of high volume metakaolin concrete. Waste brick powder (BP), after grinding, was blended with metakaolin (MK) at (50:50) \% by weight, and this blended powder was replaced for ordinary Portland cement (OPC) at ratio (50:50) \%. Six mixtures were produced, including one control mixture and five mixes that have a substitution $30 \%$ by volume of natural coarse aggregate with different ratios of blended waste clay brick aggregate (BA) and plastic aggregate (PL). The essential focus of the study is to observe density, compressive and splitting strengths of mixtures containing waste aggregate along with their workability in comparison with the control mix. The results showed that inclusion of blended wastes aggregate have adversely effect on the concrete workability, and decline the density at fresh and hardened state. Also, the use of wastes aggregate (blended or solely) has reduced the splitting strength. Moreover, compressive strength of control mix was $38.3 \mathrm{MPa}$, while mixes with waste aggregate have ranged between 32.9 42.4 $\mathrm{MPa}$. It is, therefore, more beneficial to produce sustainable concrete with moderate strength for variety applications in the construction sector.
\end{abstract}

Keywords Metakaolin, Waste Clay Brick, Waste Plastic, Green Concrete, Aggregate, Mechanical Strengths

\section{Introduction}

Concrete is by far one of the most important and extensively used building materials across the world, due to the rapid growth of population and development of urbanization cities. It is estimated that the demand for concrete will reach up to 18 billion tons per year by 2050 [1]. The high volume production of concrete has been alarming of increasing consumption of ordinary Portland cement -key ingredient- of concrete. The industrial cement does not only consume energy and significant amount of raw materials, but also contribute to $5-7 \%$ of the global carbon dioxide $\left(\mathrm{CO}_{2}\right)$ emission, annually [2]. Moreover, the concrete production is an excessive consumer of natural coarse and fine aggregate, and the future usage will lead to considerable depletion of these nonrenewable materials and increase the environment degradation $[3,4]$. Therefore, there is a major concern related to developing a green concrete that meets the future demands with low greenhouse gas emission and preservative of the natural resources. In this philosophy, the green concrete essentially incorporates waste materials either as a binder (partial cement replacement) or as recycled aggregate. A part of the effective strategy to minimize the environment impact of cement is the use of supplementary cementitious materials (SCMs) as a partial replacement of cement in concrete. 
Most of these materials are by-products like fly ash (FA), granulated blast furnace slag (GGBS), silica fume (SF) and rice husk ash (RHS), in addition to some of natural resource like calcined clay and natural pozzolan [5]. Metakaolin is one of the common calcined clay obtained by the calcination of kaolinite clay at temperature of $(650-800){ }^{\circ} \mathrm{C}$, and it possess both pozzolanic and filler effect, which enhancing the mechanical and durability properties of concrete $[6,7]$. The use of high volume of metakaolin as a partial replacement for OPC in concrete has conduced in several studies. Khatib et al. [8] evaluated the compressive strength of mortar containing high volume of MK $(10,20,30,40$ and 50) \% as cement replacement. The main finding is the optimum content of MK was $20 \%$ and beyond $30 \%$ the compressive strength starts to reduce. In the same context, Frieh et al. [9] investigated the effect of inclusion metakaolin at dosages $(10,20,30,40,50,60$ and 70$) \%$ by weight of cement on the mechanical properties of concrete. The mix of $20 \%$ MK content has provided the highest compressive strength and increasing the MK content up to $60 \%$ and $70 \%$ declines the mechanical properties significantly. Shehab El-Din et al. [10] assessed the mechanical properties of high strength concrete made from high volume MK (up to 50\%) and fibers. For the mixes without fibers, the results showed that the optimum dose of MK was $15 \%$ (by cement weight) which gained compressive strength of $74.48 \mathrm{MPa}$, while the compressive strength of mix with $50 \%$ MK was dropped to $59.89 \mathrm{MPa}$.

On the other hand, the growth of generation plastic waste, and construction and demolition (C\&D) waste has become a universal environmental crisis and a serious pollution problem. Waste clay bricks are solid waste that account for a huge amount of C\&D waste and are generated if any damages would accrue during manufacturing, construction and demolition activities, and most of these wastes end up in landfill [11]. In the same context, tremendous quantities of plastic waste are produced yearly all over the world. In 2015, the total accumulated waste plastic was 300 million tonnes, and it is estimated to reach 34 billion tonnes in 2050. This waste stream is disposed to a landfill or dumped into rivers and oceans causing considerable damage to the eco-system [12].

Thus, one of the most effective ways to minimize and reduce the amount of accumulated solid wastes $(C \& D$ and plastic) is to recycle and reuse them as part of concrete ingredients. This would not only mitigate the environmental pollution and problems of scarce landfills dumping, but would provide alternative source of binder and aggregate in place of natural resources, toward sustainable concrete technology. In the last decades many studies have been carried out with regards to the use of waste clay brick as a constituent (binder or aggregate) in concrete $[11,13,14]$. Moreover, many investigations have been devoted to studying and evaluating the concrete properties when using different types of waste plastics as a partial replacement of (fine or coarse) aggregate or as fibers [15-18]. Unlike the previous studies, the recent study has a novelty in considering the duplicate effect of three different type and form of wastes (brick powder, brick aggregate and PL aggregate) on the performance of high volume metakaolin concrete at varied substitution ratios. This study examines some physical and mechanical properties of six different concrete mixtures to provide a variety options for the selection of appropriate mix to be used in wide civil engineering applications. Consequently, this study will further promote the recycling and reusing of waste materials in the sustainable construction industry.

\section{Experimental Work}

\subsection{Materials Used}

\subsubsection{Cement}

In this study, ordinary Portland cement (OPC) type I produced by (Mass Factory) was used. The chemical composition and physical properties of cement are presented in Table 1 and 2, respectively, and they are complying with Iraqi specification No.5/1984 [19].

Table 1. Chemical composition of OPC, metakaolin (MK) and waste brick powder (BP)

\begin{tabular}{ccccc}
\hline $\begin{array}{c}\text { Oxide } \\
\text { content, \% }\end{array}$ & OPC & $\mathrm{MK}$ & $\mathrm{BP}$ & $\begin{array}{c}\text { Cement compounds } \\
\text { (Bogue) }\end{array}$ \\
\hline $\mathrm{CaO}$ & 61.9 & 1.37 & 20.2 & $\mathrm{C}_{3} \mathrm{~S}=43.90$ \\
$\mathrm{SiO}_{2}$ & 21.77 & 54.2 & 56.82 & $\mathrm{C}_{2} \mathrm{~S}=29.43$ \\
$\mathrm{Al}_{2} \mathrm{O}_{3}$ & 4.67 & 39 & 11.41 & $\mathrm{C}_{3} \mathrm{~A}=6.59$ \\
$\mathrm{Fe}_{2} \mathrm{O}_{3}$ & 3.33 & 0.92 & 2.38 & $\mathrm{C}_{4} \mathrm{AF}=10.19$ \\
$\mathrm{MgO}$ & 3.91 & 0.15 & 3.02 & \\
$\mathrm{SO}_{3}$ & 2.50 & 0.45 & 0.83 & \\
$\mathrm{Na}_{2} \mathrm{O}$ & $/$ & 0.22 & 0.84 & \\
$\mathrm{~K}_{2} \mathrm{O}$ & $/$ & 0.27 & 0.81 & \\
$\mathrm{~L} . \mathrm{O} . \mathrm{I}$ & 2.24 & 0.71 & 1.19 & \\
\hline
\end{tabular}

Table 2. Physical properties of OPC, metakaolin (MK) and waste brick powder (BP)

\begin{tabular}{|c|c|c|c|}
\hline Physical properties & $\mathrm{OPC}$ & MK & $\mathrm{BP}$ \\
\hline Specific gravity & 3.14 & 2.64 & 2.84 \\
\hline Specific surface area, (m2/kg) & 390 & 14,300 & 462 \\
\hline \multicolumn{4}{|l|}{ Setting time : } \\
\hline -Initial setting (hrs: min) & $1: 40$ & / & / \\
\hline -Final setting (hrs: min) & $4: 30$ & & \\
\hline $\begin{array}{l}\text { Retained amount on } 45 \mu \mathrm{m} \text { (No.325) } \\
\text { sieve, }(\%)\end{array}$ & / & 18.2 & 32.0 \\
\hline $\begin{array}{l}\text { Compressive Strength at } 7 \text { days, } \\
(\mathrm{MPa})\end{array}$ & 27.1 & / & l \\
\hline $\begin{array}{l}\text { Pozzolanic activity index at } 7 \text { days, } \\
(\%)\end{array}$ & l & 113.3 & 89.2 \\
\hline
\end{tabular}

\subsubsection{Metakaolin}

Iraqi kaolin clay was grinded and then burnt at $700{ }^{\circ} \mathrm{C}$ 
for two hours to produce metakaolin that was used in this study. Its chemical oxides and physical properties are shown in Tables 1 and 2, which comply with standards of ASTM C618 [20] as a natural pozzolan.

\subsubsection{Clay Brick Powder}

It is a powder produced by grinding the waste of clay brick by cyclone dust machine. This powder was tested according to the requirements of ASTM C618 [20] as similar to a natural pozzolan. The final characteristics of $\mathrm{BP}$ are illustrated in Table 1 and 2.

\subsubsection{Fine Aggregate}

The fine aggregate used in this research was natural sand with maximum size $4.75 \mathrm{~mm}$ and fineness modulus of 3.3 , and it is garaged in Zone 1 according to the Iraqi specification No.45/1984 [21].

\subsubsection{Coarse Aggregate}

Crushed gravel of $14 \mathrm{~mm}$ maximum size was used as the natural coarse aggregate (NCA). The sieve analysis and physical properties are tabulated in Table 3, and all results are satisfied with standards of Iraqi specification No.45/1984 [21].

Table 3. Sieve analysis and physical properties of NCA, BA, and PL

\begin{tabular}{cccc}
\hline \multirow{2}{*}{ Sieve size, $(\mathrm{mm})$} & \multicolumn{3}{c}{ Passing (\%) } \\
& NCA & BA & PL \\
\hline 20 & 100 & 100 & 100 \\
14 & 98.26 & 98 & 95 \\
10 & 61.38 & 60 & 60 \\
5 & 3.45 & 3.5 & 3.5 \\
\hline \multicolumn{4}{c}{ Physical properties } \\
Absorific gravity & 2.61 & 1.57 & $/$ \\
Dry rod density, $\mathrm{kg} / \mathrm{m}^{3}$ & 1.3 & 24.0 & 0.00 \\
\hline
\end{tabular}

\subsubsection{Clay Brick Waste Aggregate}

Recycled clay brick aggregate has been prepared by crushing the residual waste of clay brick from a construction site in Baghdad city. After crushing and grinding the waste brick by jaw crusher machine, the obtained particles were sieved by an electrical shaker screen to match with the grading of natural coarse aggregate under IQ.S No.45/1984 [21]. The final products are shown in Figure 1, and their characteristics are presented in Table 3.

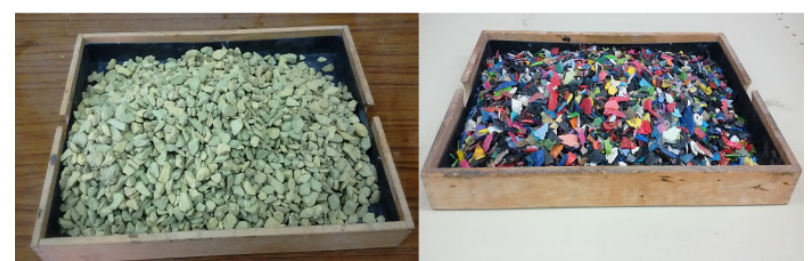

Figure 1. Recycled wastes aggregates; crushed clay brick (left); shredded waste plastic (right)

\subsubsection{Plastic Waste Aggregate}

This type of waste aggregate was produced by shredding the waste plastic which was collected from municipal waste landfill in Baghdad city. The production process included; firstly cleaning the waste plastic, then shredding it into small particles by specialist shredding plastic machine, and finally sieved the particles into close to the gradation of coarse aggregate. As shown in Figure 1, the waste plastic aggregate (PL) has a flaky irregular shape and varies in color. The properties of PL are presented in Table 3.

\subsubsection{Chemical Admixture}

High range water reducer liquid (superplasticizer/ Conplast SP 2000) conforming to ASTM C494, type G was used in this study.

\subsubsection{Water}

Ordinary tap water from local water supply network was used for the mixing and curing process.

\subsection{Mixture Proportions}

Several trial mixes have been conduced to select the control mix of high volume blended (MK-BP) concrete with target compressive strength up to $35 \mathrm{MPa}$ at 28 days. For all trail mixes the weight of cementitious materials consisted of (50\% cement: $25 \% \mathrm{MK}: 25 \% \mathrm{BP})$. The final weight ratios of control mix were ( 1 cementitious material: 1.71 fine aggregate: 2.56 coarse aggregate). Also, the water to cementitious material $(\mathrm{w} / \mathrm{cm})$ ratio was fixed to 0.31 , and the dosage of SP was $2.5 \%$ by weight of cementitious material. For other mixes, the natural coarse aggregate has been replaced with a blend of waste clay brick aggregate (BA) and waste plastic aggregate (PL) at five volumetric replacement levels as shown in Figure 2. The mix proportions and mixtures identifications used in this investigation are provided in Table 4. 


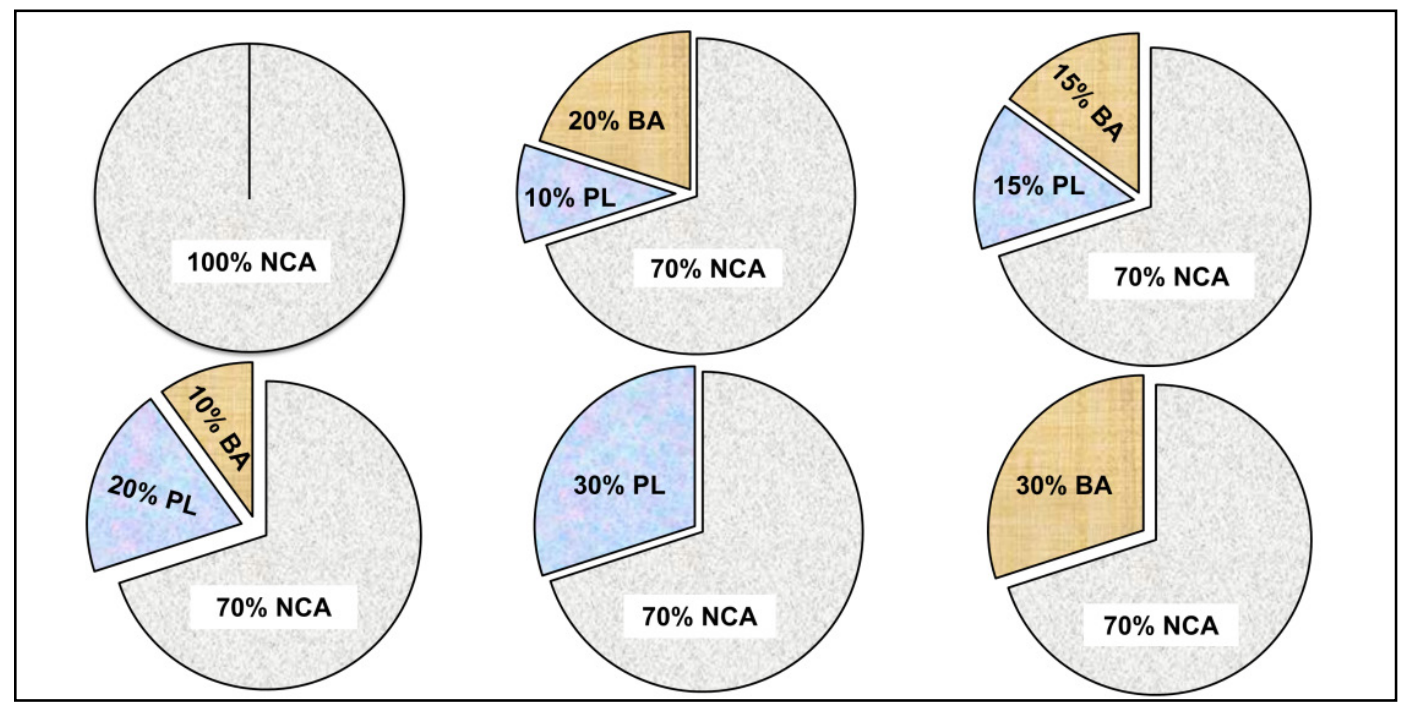

Figure 2. Volumetric proportions of natural coarse aggregate, BA and PL for each mix.

Table 4. Mix ratio and nomenclature of all mixtures

\begin{tabular}{ccccccc}
\hline \multirow{2}{*}{$\begin{array}{c}\text { Quantityof materials } \\
\left(\mathrm{kg} / \mathrm{m}^{3}\right)\end{array}$} & Ref. & 10PL:20BA & 15PL:15BA & 20PL:10BA & 30PL:0BA & 0PL:30BA \\
\cline { 2 - 7 } Cement & 210 & 210 & 210 & 210 & 210 & 210 \\
MK & 105 & 105 & 105 & 105 & 105 & 105 \\
BP & 105 & 105 & 105 & 105 & 105 & 105 \\
NCA & 1075 & 752.5 & 752.5 & 752.5 & 752.5 & 752.5 \\
BA & 0 & 126.712 & 95.034 & 36.356 & 0 & 190 \\
PL & 0 & 30.667 & 46.0 & 61.334 & 718 & 0 \\
F.A & 718 & 718 & 718 & 718 & 718 & 718 \\
SP\% & 2.5 & 2.5 & 2.5 & 2.5 & 2.5 & 2.5 \\
w/cm & 0.3 & 0.3 & 0.3 & 0.3 & 0.3 & 0.3 \\
\hline
\end{tabular}

\subsection{Preparation of Specimens and Test Methods}

An electrical drum mixer has been used to mix the ingredients of all mixtures. The fine, coarse and waste brick aggregates have been washed and prepared to be in saturated surface dry (SSD) condition. The process of mixing involved firstly addition of aggregates and cementitious materials with quite mixing. Then, the water and superplasticizer were added to the mixer with continuous rotating until a fully homogenous fresh mixture was formed. Finally, the contents of the mixer were discharged into the standard molds of concrete specimens; (cubes of $100 \times 100 \times 100) \mathrm{mm}$ and (cylinders of $100 \times 200$ ) $\mathrm{mm}$ and then compacted using a table vibrator. After casting, all specimens were covered with a plastic sheet and then demolded after 24 hours and cured by immersion in a water tank till the time of testing.

To assess the fresh and hardened properties of each mix, some tests have been conducted on different concrete specimens. Directly after the mixing process, concrete workability for each mix was determined by using slump test in accordance with ASTM C143 [22], while the fresh densities were assessed by using cubic moulds of $(100 \times 100 \times 100) \mathrm{mm}$ according to ASTM C138 [23].

The compressive strength of all concrete mixes was conducted cube specimens of $(100 \times 100 \times 100) \mathrm{mm}$ at 7 and 28 days according to B.S. 1881 part 116 [24].

The splitting tensile strength was performed according to ASTM C496 [25] using cylindrical specimens $(200 \mathrm{~mm}$ high and $100 \mathrm{~mm}$ diameter) at age of 7 and 28 days. After the splitting test, the fractured pieces of cylinders (half cylinder) have been used to measure the dry density of each concrete mixture following the procedure in ASTM C642 [26] at 7 and 28 days of curing.

\section{Results and Discussion}

\subsection{Fresh Concrete Properties}

\subsubsection{Slump}

The slump test results of all mixtures are shown in Fig 3. It can be found that the control mix has a considerable 
workability with slump of $185 \mathrm{~mm}$, whereas the mixes of waste aggregates as a partial replacement of coarse aggregate have a lower workability. The slump of 10PL:20BA, 15PL:15BA, 20PL:10BA, 30PL:0BA and OPL:30BA has dropped by $48.6 \%, 18.9 \%, 32.4 \%, 55.1 \%$ and $64.8 \%$, respectively in comparison to the control mix.

It is clear that the use of waste brick aggregate or plastic waste aggregate (solely or together) have a significant negative impact on workability of high-volume blended MK-BP concrete. This can be related to the porous structure of BA which absorbed additional water during mixing. Also, the large surface area of PL aggregate in compare with natural aggregate will need more water amount to saturation during mix process. In addition, the flaky shape of PL and rough texture of BA have restricted the fluidity of fresh concrete and reduced the workability of concrete.

\subsubsection{Fresh Density}

Figure 4 shows the measured unit weight of all mixtures in the fresh state. The fresh density of control mix was $2469 \mathrm{~kg} / \mathrm{m} 3$, and this value reduced when the coarse aggregate was replaced with recycled BA and PL aggregate. In comparing to the reference mix, the reduction in fresh density for mixes 10PL:20BA, 15PL:15BA, 20PL:10BA, 30PL:0BA and 0PL:30BA reached up to $4.9 \%, 5.1 \%, 7.9 \%$, $8.3 \%$ and $4.6 \%$, on respect. This can be explained by the low bulk density of BA and PL aggregates that substituted the coarse aggregate which has a higher density.

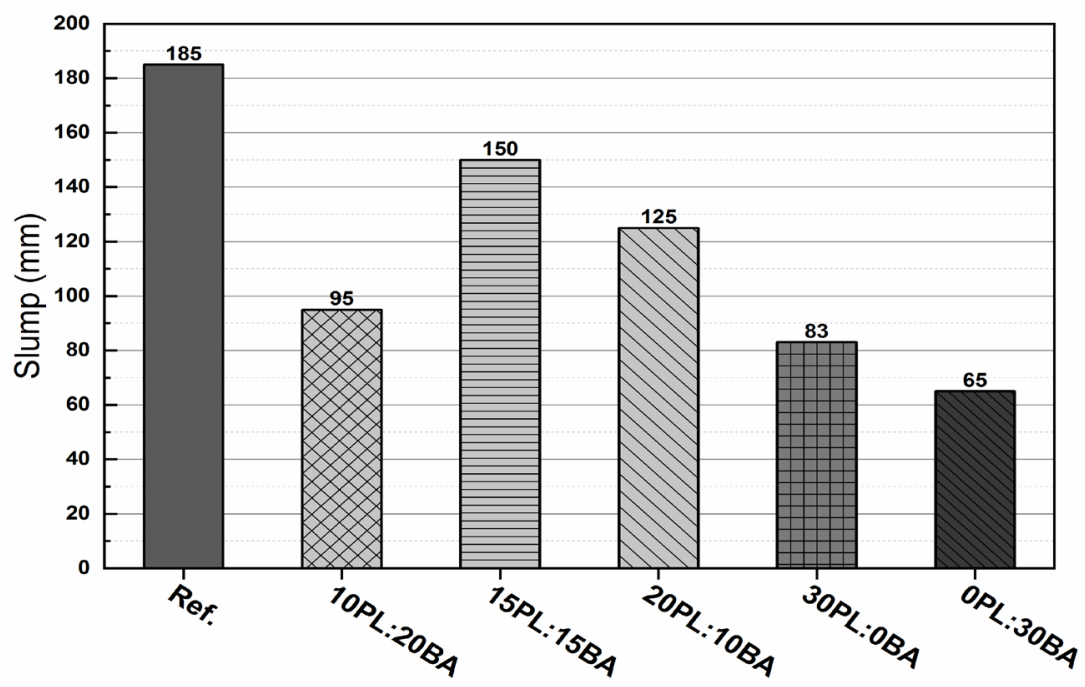

Mix Code

Figure 3. Slump values of all mixtures

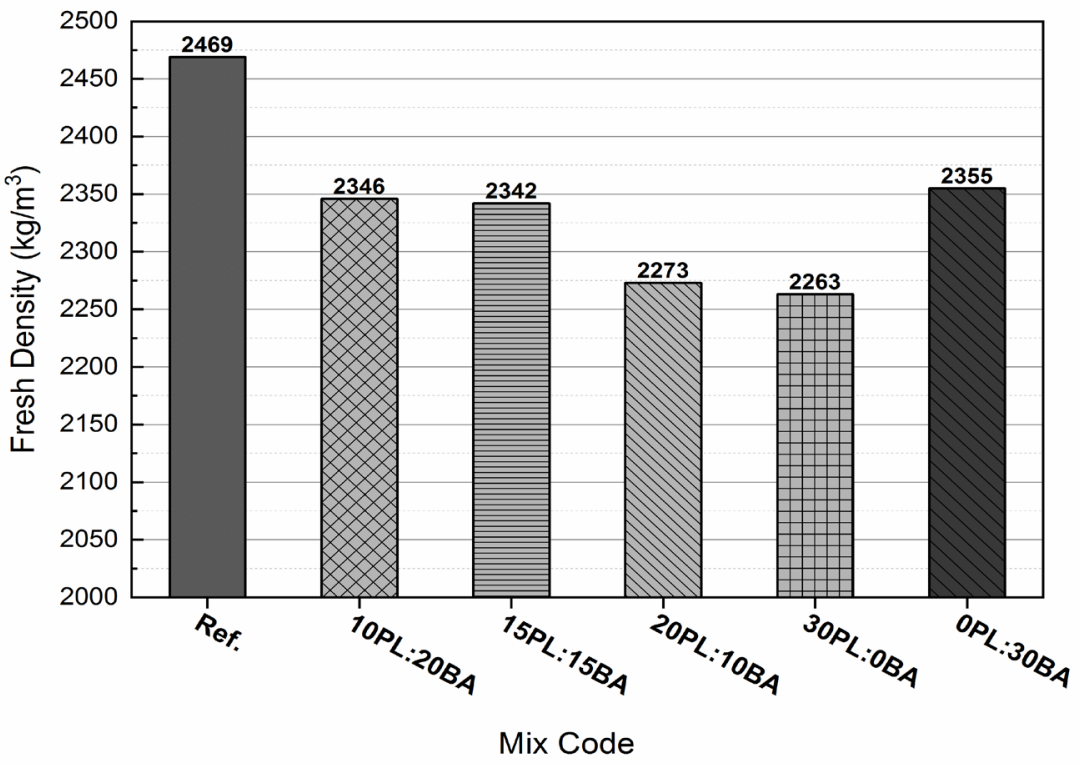

Figure 4. Fresh density of all mixtures 


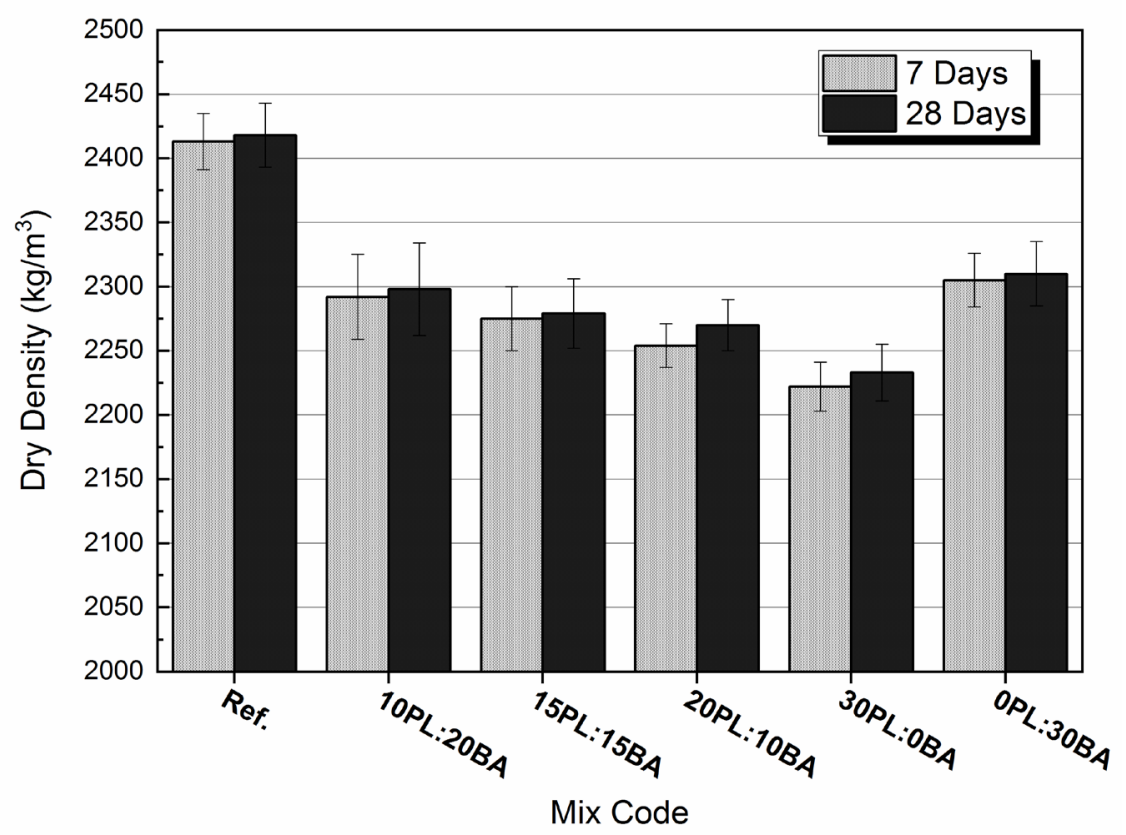

Figure 5. Dry density of all mixtures at age of 7 and 28 days

\subsection{Hardened Concrete Properties}

\subsubsection{Dry Density}

The hardened densities of all mixtures at age of 7 and 28 days are presented in Figure 5. It can be seen that the dry density for each mix at 28-days is slightly higher than those of 7 days, due to continuous cement hydration and filling the voids within matrix. The dry density of mixtures containing BA and PL aggregate were expected to be lower than the control mix made from $100 \%$ natural aggregate, as BA and PL are about $41 \%$ and $71 \%$ lighter than normal aggregate, respectively. It can be concluded from results that the dry density of mix 0PL:30BA was second to control mix, while the mix 30PL:0BA showed the lowest density.

\subsubsection{Compressive Strength}

The results of compressive strength of all mixtures, which are average values of three specimens at ages of 7 and 28 days, are shown in Figure 6. It is expected that the compressive strength increased with curing age; and this indicate the continuous pozzolanic activity of blended MK$\mathrm{BP}$ with calcium hydroxide $(\mathrm{CH})$ from cement hydration to form secondary (C-S-H) gel. For instance, the compressive strength of control mix at 7 days has developed up to
$14.17 \%$ after 28 days. In general, the control mix of high volume blended (MK-BP) concrete has gained a compressive strength of $38.3 \mathrm{MPa}$ at 28 days.

It can be noticed that compressive strength varies when the type and replacement level of aggregate changes. Whereas the blending of waste aggregate at dosage of $10 \% \mathrm{PL}-20 \% \mathrm{BA}$, and $20 \% \mathrm{PL}-10 \% \mathrm{BA}$ has slightly increased the compressive strength by $1.3 \%$ and $1.5 \%$, respectively, in compariso with the control mix at 28 days. Also, the use of $30 \%$ BA as a substitute of coarse aggregate would improve the compressive strength up to $10.8 \%$. This improvement may be attributed to compatibility between MK-BP hydration product gel and clay brick aggregate. Moreover, the rough texture surface and porous structure of BA can provide a good adhesion with cement gel in the interfacial transition zone (ITZ). On contrary of that, mixes of 15PL:15BA and solely of 30\%PL aggregate have shown reduction in compressive strength reach to $11 \%$ and $14.1 \%$, respectively. Since the PL aggregate has lower hardness than natural aggregate, therefore, a noticeable reduction in strength of concrete matrix will present. On the other hand, the smooth surface of PL aggregate will prevent the bonding between cement paste and PL aggregate in the interaction zone. Consequently, more defects in (ITZ) will take place which negatively impact the concrete strength. 


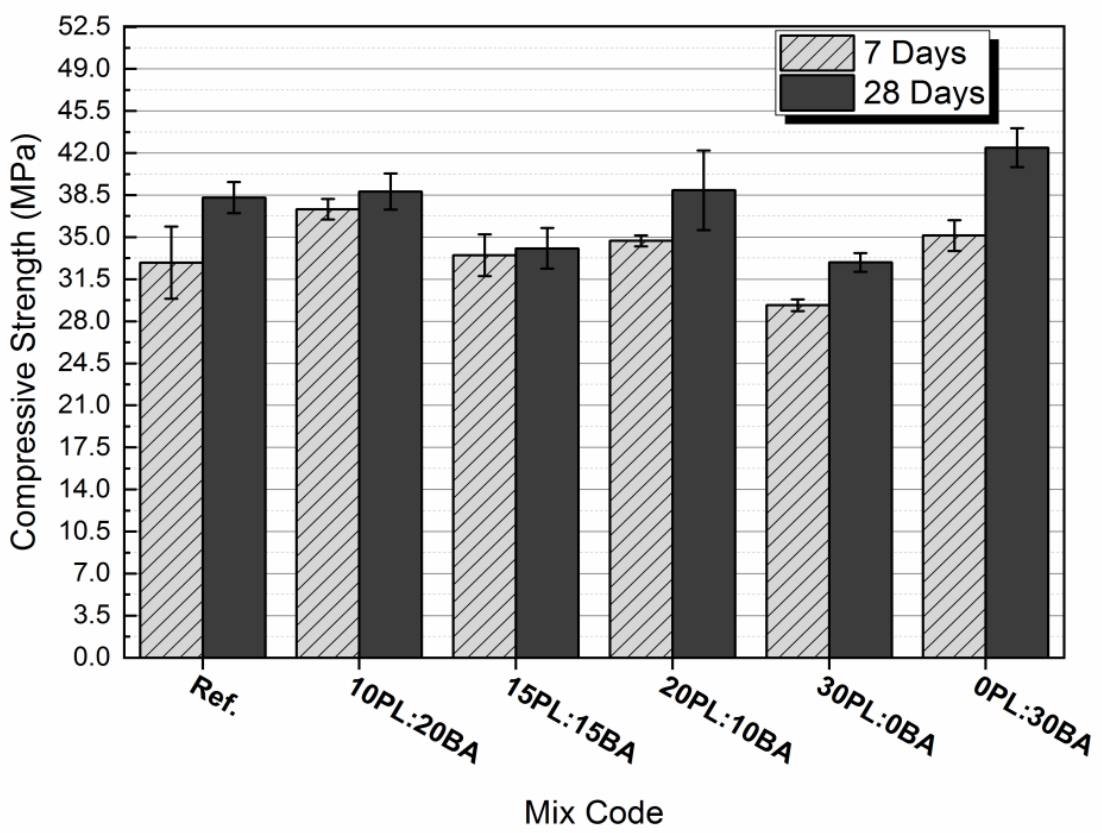

Figure 6. Compressive strength of all mixtures at age of 7 and 28 days

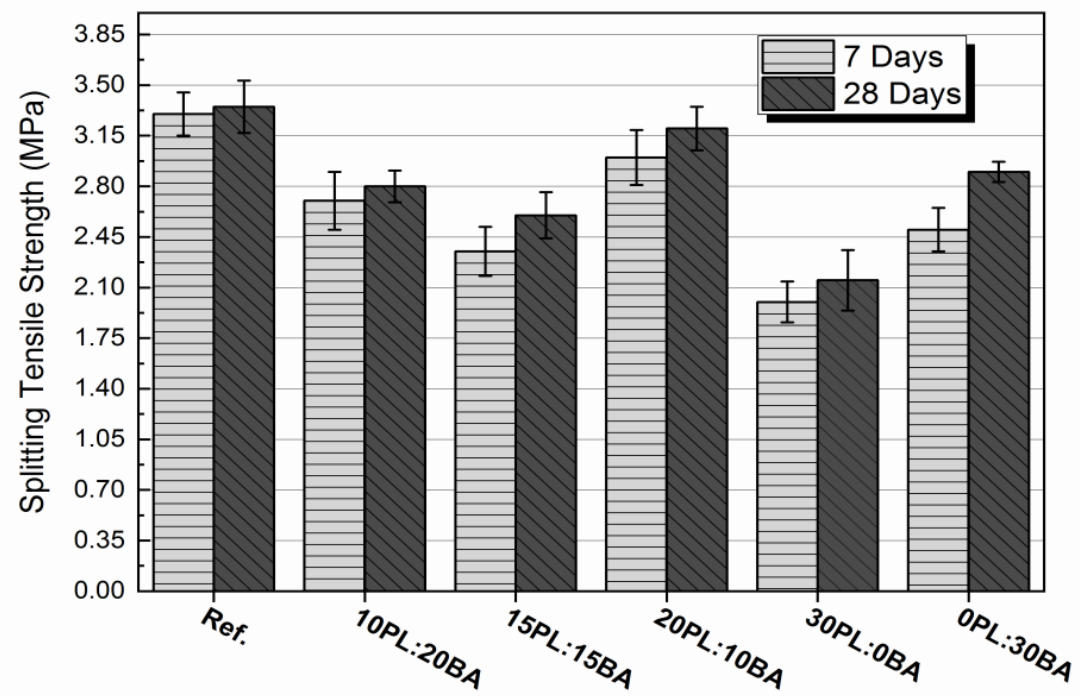

Mix Code

Figure 7. Splitting tensile strength of all mixtures at 7 and 28 days

\subsubsection{Splitting Tensile Strength}

Both high volume blended MK-BP concrete mixtures with and without waste aggregates were tested for splitting tensile strength at 7 and 28 days, as presented in Figure 7. Similarly to compressive strength, the splitting strength of all mixes has increased with time as mentioned previously. Generally, the results revealed that all mixtures including waste brick aggregate or plastic aggregate (blended or solely) have given lower splitting strength. Comparing with control mix, the reduction in 28- day splitting strength of mixes 10PL:20BA, 15PL:15BA, 20PL:10BA, 30PL:0BA and 0PL:30BA were $16.4 \%, 22.3 \%, 4.4 \%$,
$35.8 \%$ and $13.4 \%$, respectively. The less strength and hardness of BA and PL particles in comparison with natural aggregate would reduce the resistance of concrete matrix against shear tensile strength that occurs under load.

On the other hand, the incorporation of waste plastic as a part of aggregate in this type of concrete has changed the failure mode of specimens under tensile load. As shown in Figure 8 , the cylinders with $30 \% \mathrm{PL}$ content did not split into two pieces after tensile loading, meanwhile the control and OPL:30BA mixes have shown a full disintegration. This behavior can be related to the flaky and longitudinal shape of PL aggregate that acts like a bridge and connect the composite without separating. 


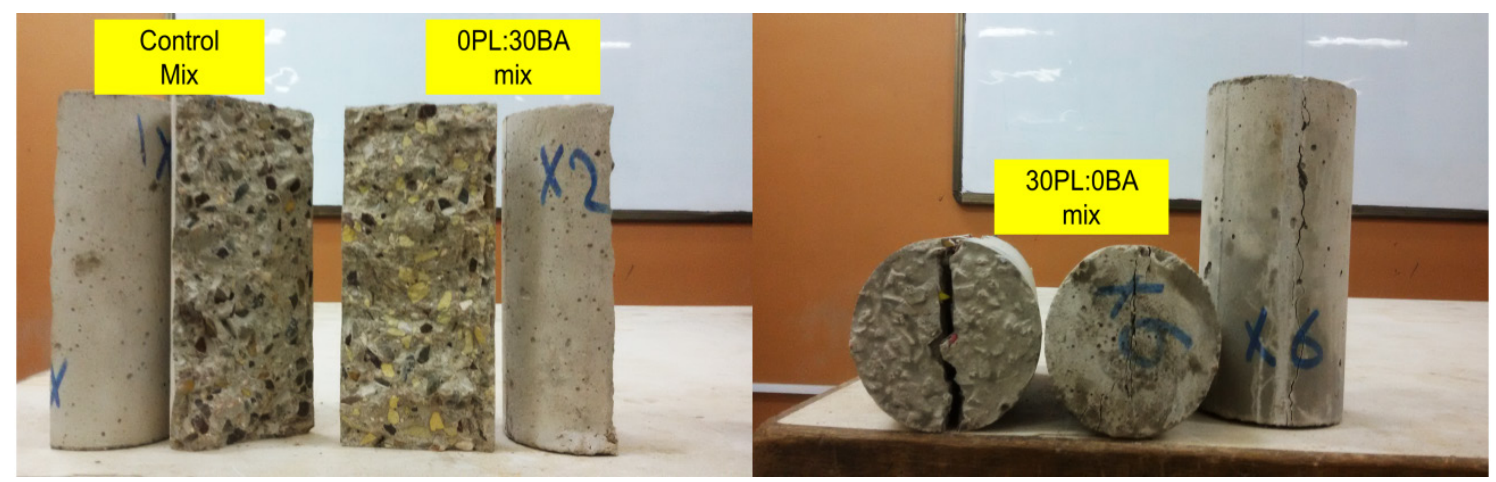

Figure 8. Failure mode of cylinders after splitting tensile test

\section{Conclusions}

This study introduced the performance of high volume ternary blended metakaolin (MK) and waste brick powder (BP) concrete wherein the natural coarse aggregate has a volumetric replacement by $30 \%$ with two types of waste materials; clay brick aggregate (BA) and plastic aggregate (PL). Based on some physical and mechanical laboratory tests, the main conclusions are emphasized as following:

- It is possible to replace $50 \%$ of cement weight content with a blended of $50 \% \mathrm{MK}$ and $50 \% \mathrm{BP}$ as a cementitious material to produce sustainable high volume blended (MK-BP) concrete with target strength up to $38 \mathrm{MPa}$ at 28 days.

- The inclusion of BA and PL aggregate as binary or solely will adversely affect concrete workability. The optimum replacement dosage is 15PL:15BA with lowest reduction in slump, while the minimum slump is $65 \mathrm{~mm}$ for mix of $0 \mathrm{PL}: 30 \mathrm{BA}$.

- $\quad$ The fresh and dry densities of high volume blended (MK-BP) concrete decrease as the natural aggregate was substituted with waste BA and PL. The lowest density at fresh and hardened state was $2263 \mathrm{~kg} / \mathrm{m} 3$ and $2233 \mathrm{~kg} / \mathrm{m} 3$, respectively, for mix 30PL:0BA.

- $\quad$ The use of BA and PL as aggregate at specific dosages will increase the compressive strength of concrete. Among mixtures of blended waste aggregate, the mix of $20 \% \mathrm{PL}: 10 \% \mathrm{BA}$ gained highest strength of 38.9 $\mathrm{MPa}$, while the use of $30 \% \mathrm{BA}$ increased the compressive strength up to $42 \mathrm{MPa}$.

- The mixes containing BA and PL aggregate have recorded low values of splitting strength in comparison to control mix, especially for $30 \% \mathrm{PL}$ content. The optimum replacement level is $20 \% \mathrm{PL}$ and $10 \% \mathrm{BA}$ with a splitting strength of $3.2 \mathrm{MPa}$.

Finally, it can be concluded that development of high volume blended (MK-BP) concrete with recycled waste aggregate has great benefits for the environment in relation to minimizing $\mathrm{CO}_{2}$ emission, consumption of natural resources and reduces the pollution. Moreover, the sufficient workability and compressive strength of this green concrete will provided wide using in civil engineering sector, especially of precast applications like building block and interlocking paving units.

\section{REFERENCES}

[1] Herath C., Gunasekara C., Law D.W., Setunge S., "Performance of high volume fly ash concrete incorporating additives: A systematic literature review," Construction and Building Materials, vol. 258, no.120606, pp. 1-13, 2020. DOI: 10.1016/j.conbuildmat.2020.120606

[2] Nassar R. U-D., Sediadi E., Elmenghawi F., "Sustainable, energy efficient and economical design of single-family dwellings," Civil Engineering and Architecture, vol. 9, No. 4, pp. 1048 - 1056, 2021. DOI: 10.13189/cea.2021.090407.

[3] Ghorbani S., Sharifi S., Ghorbani S., Tam V. W., de Brito J, Kurda R., "Effect of crushed concrete waste's maximum size as partial replacement of natural coarse aggregate on the mechanical and durability properties of concrete," Resources, Conservation and Recycling, vol. 149, pp. 664-673, 2019. DOI: $10.1016 /$ j.resconrec.2019.06.030

[4] Kubissa W., Jaskulski R., Koper A., Supera M., "High performance concrete with SCM and recycled aggregate," In Key Engineering Materials, vol. 677, pp. 233-240, 2016. DOI: 10.4028/www.scientific.net/KEM.677.233.

[5] Rahla K M, Mateus R, Bragança L., "Comparative sustainability assessment of binary blended concretes using Supplementary Cementitious Materials (SCMs) and Ordinary Portland Cement (OPC)," Journal of Cleaner Production, vol. 220, pp. 445-459, 2019. DOI: 10.1016/j.jclepro.2019.02.010

[6] Li Q., Geng H. N., Huang Y., Shui Z. H., "Hydration Products, Microstructure and Durability of Concrete with Metakaolin Addition," In Key Engineering Materials, vol. 680, pp. 420-428, 2016. DOI: 10.4028/www.scientific.net/K EM. 680.420

[7] Chandak M. A., and Pawade P.Y., "Compressive Strength and Ultrasonic Pulse Velocity of Concrete with Metakaolin," Civil Engineering and Architecture, vol. 8, No. 6, pp. 1277 1282, 2020. DOI: 10.13189/cea.2020.080611.

[8] Khatib J. M., Negim E. M., Gjonbalaj E., "High volume metakaolin as cement replacement in mortar," World journal of chemistry, vol.7, no. 1, pp. 7-10, 2012, DOI: 10.5829/idosi.wjc.2012.7.1.251 
[9] Frieh K. J., Abbas W. A., Hamid M. M., "Some Properties of Concrete Containing High Fraction Volume of Metakaolin,", Engineering and Technology Journal, vol. 32, Part (A), No.1, pp. 230-248, 2014.

[10]El-Din, H.K.S., Eisa, A.S., Aziz, B.H.A. and Ibrahim, A., "Mechanical performance of high strength concrete made from high volume of Metakaolin and hybrid fibers," Construction and Building Materials, vol. 140, pp.203-209, 2017. DOI: 10.1016/j.conbuildmat.2017.02.118

[11] Wong, C.L., Mo, K.H., Yap, S.P., Alengaram, U.J. and Ling, T.C., "Potential use of brick waste as alternate concrete-making materials: A review," Journal of cleaner production, vol. 195, pp. 226-239, 2018. DOI: 10.1016/j.jclepro.2018.05.193

[12] Mazhandu, Z.S., Muzenda, E., Mamvura, T.A., Belaid, M. and Nhubu, T., "Integrated and consolidated review of plastic waste management and bio-based biodegradable plastics: challenges and opportunities," Sustainability, vol. 12, no.20:8360, pp.1-57, 2020. DOI: 10.3390/su12208360

[13] Liu, Q. and Zhang, X.N., "Experimental study on the mixture ratio and the compressive strength of concrete with Recycle crushed brick coarse Aggregate," In Applied Mechanics and Materials, vol. 584-586, pp. 1362-1365, 2014. DOI: 10.4028/www.scientific.net/amm.584-586.1362

[14] Olofinnade, O.M., Ede, A.N., Ndambuki, J.M. and Bamigboye, G.O., "Structural properties of concrete containing ground waste clay brick powder as partial substitute for cement," In Materials Science Forum, vol. 866, pp. 63-67, 2016. DOI: 10.4028/www.scientific.net/msf. 866.63

[15] Islam, M.J., Meherier, M.S. and Islam, A.R., "Effects of waste PET as coarse aggregate on the fresh and harden properties of concrete," Construction and Building Materials, vol. 125, pp. 946-951, 2016. DOI: 10.1016/j.conbuildmat.2016.08.128

[16] Jnr, A.K.L., Yunana, D., Kamsouloum, P., Webster, M., Wilson, D.C. and Cheeseman, C., "Recycling waste plastics in developing countries: Use of low-density polyethylene water sachets to form plastic bonded sand blocks," Waste management, vol. $80, \quad$ pp. $112-118,2018$. DOI: 10.1016/j.wasman.2018.09.003

[17] Perera, S., Arulrajah, A., Wong, Y.C., Horpibulsuk, S. and Maghool, F., "Utilizing recycled PET blends with demolition wastes as construction materials," Construction and Building Materials, vol. 221, pp.200-209, 2019. DOI: 10.1016/j.conbuildmat.2019.06.047

[18] Hadj Mostefa, A., Slimane, M., "Study of Concretes Reinforced by Plastic Fibers Based on Local Materials," International Journal of Engineering Research in Africa, vol. 42, pp. 100-108, 2019. DOI:10.4028/www.scientific.net/jer a. 42.100

[19] IQ.S No.5, Portland cement. Central Organization for Standardization and Quality Control in Iraq, 1984.

[20] ASTM C618-19, Standard Specification for Coal Fly Ash and Raw or Calcined Natural Pozzolan for Use in Concrete, ASTM International, West Conshohocken, PA, 2019.

[21] IQ.S No.45, Aggregate from natural sources for concrete. Central Organization for Standardization and Quality Control in Iraq, 1984.

[22] ASTM C143 / C143M-05, Standard Test Method for Slump of Hydraulic-Cement Concrete, ASTM International, West Conshohocken, PA, 2005.

[23] ASTM C138 / C138M-17a, Standard Test Method for Density (Unit Weight), Yield, and Air Content (Gravimetric) of Concrete, ASTM International, West Conshohocken, PA, 2017.

[24]BS 1881: Part 116, Testing Concrete. Method for Determination of Compressive Strength of Concrete Cubes, British Standard Institution. 1983.

[25] ASTM C496 / C496M-17, Standard Test Method for Splitting Tensile Strength of Cylindrical Concrete Specimens, ASTM International, West Conshohocken, PA, 2017.

[26] ASTM C642-13, Standard Test Method for Density, Absorption, and Voids in Hardened Concrete, ASTM International, West Conshohocken, PA, 2013. 